\title{
LONELINESS AND CONTEMPORARY WORK: MULTIPLE PERSPECTIVES OF ANALYSIS
}

\author{
MARCUS V. S. SIQUUEIRA ${ }^{1}$ \\ (iD https://orcid.org/0000-0002-4787-7016 \\ CLEDINALDO A. DIAS \\ (iD) https://orcid.org/0000-0002-7707-9664 \\ BÁRBARA N. MEDEIROS \\ (iD) https://orcid.org/0000-0002-2262-8208
}

To cite this paper: Siqueira, M. V. S., Dias, C. A., \& Medeiros, B. N. (2019). Loneliness and contemporary work: Multiple perspectives of analysis. Revista de Administração Mackenzie, 20(2). doi:10.1590/1678-6971/eRAMG190058

Submission: Apr. 23, 2018. Acceptance: Sept. 17, 2018.

Universidade de Brasília (UnB), Brasília, DF, Brazil.

\section{(cc) BY This is an open-access article distributed under the terms of the Creative Commons Attribution License.}

\footnotetext{
This paper may be copied, distributed, displayed, transmitted or adapted if provided, in a clear and explicit way, the name of the journal, the edition, the year and the pages on which the paper was originally published, but not suggesting that RAM endorses paper reuse. This licensing term should be made explicit in cases of reuse or distribution to third parties. It is not allowed the use for commercial purposes.

Este artigo pode ser copiado, distribuído, exibido, transmitido ou adaptado desde que citados, de forma clara e explícita, o nome da revista, a edição, o ano e as páginas nas quais o artigo foi publicado originalmente, mas sem sugerir que a RAM endosse a reutilização do artigo. Esse termo de licenciamento deve ser explicitado para os casos de reutilização ou distribuição para terceiros. Não é permitido o uso para fins comerciais.
} 


\section{ABSTRACT}

Purpose: To reflect on the faces of loneliness within the contemporary work context contemplating it: 1 . as affect that results from coexistence and social interaction; 2 . as a symptom of unease at work, the result of managerial ideology; and 3. as a source of development, reinvigoration and formation for an individual.

Originality/value: This study is relevant because it makes it possible for us to take a new look at loneliness within the work context as a resource to liberate the worker.

Design/methodology/approach: This study is a theoretical essay, based on a review of the literature of various fields of knowledge (sociology, psychology, philosophy and administration), and is an interdisciplinary reflection on various currents of thought which discuss the faces of loneliness.

Findings: We have found that loneliness in contemporary work can be seen as harmful, given the everyday violence within the organizational environment, work that has lost its meaning, a lack of solidarity among workers, or it can be seen as a necessary virtue for the development and emancipation of the subject. Even though this is seen by most studies as a negative phenomenon, it is not restricted to physical distance, and much less trying to escape from life. It can also be seen as the search to awaken something in oneself and repositioning of the values and culture inculcated by organizations.

\section{KEYWORDS}

Loneliness. Work. Clinical sociology. Managerial ideology. Violence. 


\section{INTRODUCTION}

The analysis of work in contemporary life demands a multifaceted perspective in order to encompass all of its various contradictions. In the face of the paradoxes that make up work and its relationship with management, it is necessary to reevaluate the individual-company relationship based on paradigms that do not fit within the hegemony of organizational studies. Each time that a new model of human relationships is formed, we need to find new ways of visualizing, experiencing and attaching new forms of significance to the working world (Graceffa \& Heusch, 2017), which over time has maintained itself as a "characteristic deeply established within modernity” (Granter, 2009, p.207).

The attaching of new forms of significance to work touches on aspects of modern social life, in terms of physical space, hierarchies, innovation and relationships (Delbridge \& Sallaz, 2015; Praun, 2016; Sewell \& Taskin, 2015); the reinvention of productive forces and the exploitation of immaterial labor (Valencia, 2016); various types of cooperation/association (Garrett, Spreitzer, \& Bacevice, 2017; Graceffa \& Heusch, 2017); mobility, flexibility and virtual connections (Symon \& Pritchard, 2015); affects that shape organizational life (Dashtipour \& Vidaillet, 2017) and the logic of consumption (Bauman, 2003; Chertkovskaya, Korczynski, \& Taylor, 2017). However, despite these diverse configurations, these changes "occur in the field of morphology, rather than in the meaning of work" (Valencia, 2016, p. 367).

Even though it is no longer seen as "the essence of man," work continues to occupy a central place in human life (Enriquez, 2013, p. 163). This fact may be explained by the meaning that is attributed to it as a space of idealization and realization. Subject to capitalist and organizational desires, workers seek realization in their objectives related to their professional responsibilities. This implies a fantastical search fed by managerial practices which seek to provide a balance between life and work (Bloom, 2016). These practices help destroy the moral commitment of work (Bauman, 2003) and establish the worker's alienation through an organizational discourse which promises self-realization and the attainment of desires (Siqueira, 2009a), leading workers to ignore the exploitation that they suffer, which leads to isolation and loneliness among other emotions.

The contemporary organizational discourse, keeping in mind its paradoxes and the contradictory demands of cooperation and competitiveness, opens up a need for space to discuss loneliness in the work dynamic and environment, including a critique of the radical humanist paradigm founded 
by the contributions of the Frankfurt School and its socio-organizational criticism from a psycho-social perspective. It is necessary to rethink loneliness in the face of: 1 . The objectification of the worker, in which the individual is submitted to an ideological managerial context; 2 . The intensification of work, which is already precarious in and of itself; 3 . The hegemony of rationality, which leaves little room for a wider dialogue about the working environment; 4. Disputes for power, which are a significant part of situations involving moral harassment; 5 . The insignificance attributed to subjectivity; 6. The indifference to previous contributions; 7 . Guilt in not fulfilling organizational demands and; 8 . The shame of being submitted to organizational actions that are unethical and/or immoral in such a servile manner.

Loneliness in this way leaves its singular nature and becomes plural, in a plural dimensionality that manifests itself in suffering, pain, and the individual's physical or psychological illness, or even this person's real or metaphorical death. In this sense, loneliness cannot and should not be instrumentalized as the incapacity to work with others, but as a symptom of the reality of work, which denies the interior self, despite all the epistemological and ontological discussions regarding this theme.

In addition, loneliness can and needs to be the object of analyses with other focuses, such as the opportunity to become oneself again - a necessary solitude achieved by distancing oneself from a fly-infested market, as mentioned by Nietzsche (2011) in "Thus Spoke Zarathustra" This loneliness is fundamental to a repositioning of the individual in relation to his or her life, including the work dimension. Perhaps it can also be said and considered to be something which has to do with a minimum level of emancipation, a term dear to the critical theory related to the individual faced with this situation. It is the resistance to repression and the search for civilized escapes.

Reflections of this nature in the theoretical and critical epistemological environment are justified in compensating for the lack of studies related to the consequences of contemporary work in the loss of social ties (affects) and the workers' subjectivity, aspects which are still relatively unexplored in the face of loneliness within an organizational context, permeated by the advance of the managerial ideology. Moreover, it spans organizational studies that utilize interdisciplinary epistemology, including philosophy, sociology and anthropology in the search for understanding and the analysis and interpretation of essential issues in terms of individual-company relations, in order to rethink organizational practices. Contemplating these aspects makes it possible to ask: what are the faces of loneliness in the context of contemporary work and managerial ideology? 
Thus, respecting the different meanings attributed by individuals to work and loneliness, as well as organizational and managerial models, this essay seeks to reflect the faces of loneliness within the contemporary work context, contemplating it: 1 . As affect that results from co-existence and social interaction; 2 . As a symptom of unease at work, the results from managerial ideology; and 3. As a source of development, reinvigoration and formation for the individual.

The first face is delineated by the theoretical perspective of valuing work as the deepening of one's relationship with the other, as a construct of collective work in which the other is essential in the development of this act. The purpose of work consists of establishing a new perspective in terms of human coexistence, which is a theme dear not only to psychosociology, but also other closely related epistemologies such as the Dejourian psychodynamics of work. When we reflect on coexistence, we come into contact with a discussion of the other, and this person's role in the construction of one's own subjectivity. The other is a mirror, a friend, a competitor, who in the end helps one construct oneself. And in the contemporary work context, in environments in which there are frequent reconstructions of production and which are characterized by a pressure for results, which exalt competition and individualism, it is important to reflect on the space of the subject within this dynamic, even if it is difficult to say subject in the post-modern perspective, which looks to Nietzsche as one of its main theoretical supporters.

The second face has been developed based on clinical results and critiques of the social sciences, deepening discussions related to managerial ideology, modern organizational discourse and individualism. It seeks to analyze loneliness as a symptom of unease at work, which it is due to the effects of managerial ideology on the subjectivity of the worker, including what we refer to as symbolic violence, which is rarely identified and observed in daily work life. It rarely comes to mind that processes such as the homogenization of individual conduct is frequently a form of violence, denying the individual, restricting his or her creativity and not respecting this person's uniqueness.

The third perspective of analysis refers to the physical distance from the other, the diminishing of ties of coexistence as a mechanism which is minimally subject, through the strengthening of individualities, to the opening up of space for the edification of scholé, a heroic laziness, creating breaks in one's solitary existence, in order to minimize the effects of socioorganizational controls. From this perspective, we can use as a reference one of the main philosophers of suspicion: Nietzsche. Observing the Nietzschean 
critique of the herd mentality and the need for mounting solitude to reinvigorate and construct oneself: making oneself a work of art. In this manner, loneliness can also be understood as being essential to the development of the individual and his or her reinvigoration and human formation.

This work is characterized as a theoretical essay, based on literature from various fields of knowledge (sociology, psychology, philosophy and administration) and consists of an interdisciplinary reflection on the currents of thought that discuss the faces of loneliness.

\section{BETWEEN THE PSYCHE AND SOCIOLOGY:} THE SOCIO-CLINICAL PERSPECTIVE OF LONELINESS

In reflecting on the phenomenon of loneliness within the work context in light of the socio-clinical perspective, it is necessary to understand the reflections made which dilute the association between the social and the individual, the collective and the psychic, compromising the analysis of socio-psychic processes that constitute individuals and "their subjective dynamics, their social places and ways of being in the world and their identities. Far from opposing each other, the social and the psychic obey their own laws and support each other and are intertwined in multiple complex combinations" (Gaulejac \& Takeuti, 2013, p. 68).

The challenge is to understand external (as phenomena that structure, determine and condition social existence) and internal social facts (as phenomena that act by themselves) that extend beyond the work environment, because to clinical sociology "the social and the psychic feed each other permanently in an inseparable form" (Hanique, 2009, p. 9). As Nunes and Silva state (2018, p. 183), this attempt to understand human phenomena "through the articulation between psychic and social dimensions is not something original," however, it raises new considerations in terms of human beings, their affective and psychic dimensions, and their social environment.

Clinical sociology's choice of these reflections is based on its critical epistemological affiliation, which is explained by one of the aspects presented by Nunes and Silva (2018, p. 184) as comprehensive sociology, which is based on the Weberian maxim of "comprehending an act based on the meaning that actors attribute to it", which implies understanding loneliness based on the meanings that are attributed to it within the work context, 
making it possible to question the dominant discourse of loneliness as pathology and suffering.

Identifying the work space as a component of social interaction makes it possible to analyze how it interacts, combines, influences, expands and connects with the worker's psychic components (Fry \& Bloyce, 2017; Hanique, 2009; Ozcelik \& Barsade, 2018; Praun, 2016), making other interpretations of loneliness possible. This articulated and integrated analysis makes it possible to deconstruct concrete situations from the working world and restore the subject's place in the clinical social sciences approach (Siqueira, 2009b). This fact leads us to a discussion of the meanings attributed to loneliness in the contemporary work context.

In sociological terms, Gomes (2001) defines loneliness as the byproduct of the individual's social construction. In affirming his or her individuality, a person also affirms the fragmentation of his or her social universe and isolation from the other. This isolation, however, can become unbearable and lead to an attempt to overcome this through interpersonal relationships and engagement (Chan \& Qiu, 2011; Öge, Çetin, \& Top, 2018). In psychological terms this can be characterized as the affective absence of the other, which is intimately related to the feeling and the sensation of being alone.

Looking at loneliness in this sense, it is related to the affective ties that work as a social construction can offer. As a space of socialization, individuals construct, identify and see themselves subjectively at work. The perspective offered by the other (colleague, client, manager, or employer) contributes to the expansion of the unease that loneliness can generate as noted by Öge, Çetin and Top (2018, p. 25) when they state that "paternalistic leadership through increased engagement at work diminishes loneliness in the work environment and the level of family conflicts in the work of air traffic controllers in Turkey." In this sense, working is not just exercising productive activities, but also "coexistence," given that human beings need work as a means to receive recognition as social beings (Dejours, 2006). This is an argument "to protect the ego and the realization of the ego, or in other words, the subjective world and subjective health" (Dejours, 2006, p. 62). Removing oneself from the perspective of the other irritates and saddens individuals, draining them of meaning and instills a feeling of loneliness. This fact is appreciated by Garrett, Spreitzer and Bacevice (2017, p. 1), who explain that "to the extent that more individuals are working remotely, many feel more and more isolated and socially adrift."

While we cannot ignore the individual differences and behavior of human beings and their relationships with different types of organizations 
and socialization at work, the fear of isolation leads individuals to seek alternatives that give them some form of outside perspective, which ensures that they are not alone, because being alone is seen as being weak, incompetent, inefficient, and defeated. Having another's perspective ends up functioning as a comfort mechanism and a resource to deny loneliness.

Even though there are frequent changes in the working world, individuals seek to face the challenge of isolation. Garrett et al. (2017, p. 2) mention that many independent workers choose to work in coworking space, or in other words, "shared spaces where individuals perform their own work, but in the presence of others with the express purpose of being part of a community." The authors admit that in addition to the physical benefits attributed to the work place, these spaces also feature the social aspects of living in a community and creating social ties.

Under the focus of sociology that is inseparable from psychic aspects, Pocinho and Macedo (2017, p. 54) argue that "loneliness comes from the impact of external factors such as social deficits, unrealistic expectations, and life events on internal factors, such as cognitive and affective dysfunction and, to the same extent, personality traits," elements that favor the suffering that loneliness can provoke. This prerogative can justify the dominance of studies that allude to "the perverse and pernicious influence of loneliness" (Ozcelik \& Barsade, 2018, p. 3) and its influence in alienation at work (Santas, Isik, \& Demir, 2016). Frustrations with work due to organizational demands, of not performing, of not being a hero, of not fulfilling the organization's countless promises, lead the subjects to withdraw from each other, from shame or rivalry, creating social isolation and as a result pathological loneliness.

Oliveira (2010) describes the complexity and subjectivity that characterize loneliness. He pays attention to the fact that the relationships among loneliness, isolation and living alone are not easily explained or understood. The existence of a vast social network, for example, does not imply the existence of a close relationship or the absence of loneliness. More than this, loneliness, as Kuznier mentions (2016, p. 29), presents a "delicate boundary between being briefly lonely and intrinsically lonely," which complicates the understanding of this phenomenon as well as its representation as an experience of the personal sphere. Loneliness is not shared, it is solitary by definition, because it is understood to be part of private life. However, feelings cannot be removed from the social environment, because it is in this field that loneliness reveals itself in terms of its strategies for maintenance or transformation (Dornelas, 2010). 
Within the sociopsychological context, reflecting on loneliness at work implies a complex task, which bears in mind collective and individual aspects that are intertwined with this theme. At the same time in which new work configurations, such as telework, home offices, and virtual and remote services guide social isolation, individuals also seek ways to not envision themselves as alone and to be associated with some group, creating refuges to ignore loneliness and meet each other to obtain the other's perspective. These ties express possibilities of power, ferocity, enthusiasm and heroism, instincts that loneliness does not allow them to feel, because ties to a group undo the impossibility of their existence (Freud, 1990). It should be noted, however, that despite these resources, loneliness is part of the essence of human existence and "dealing with this reality, accepting it and learning to guide one's own life with satisfaction are part of the human condition" (Tomei \& Fortunato, 2008, p. 18).

The psychic phenomenon of loneliness, which includes ultra-individual experiences and their relationships with the social arena raises questions about its effects on the social field of contemporary work, which is a subject that has not been widely explored in the academic literature or has been treated from the point of view of work pathologies and their effects on the worker's subjectivity as a symptom of unease at work.

\section{MANAGERIAL IDEOLOGY AND UNEASE AT WORK: THE HARMFUL SIDE OF LONELINESS}

The dilemmas that intersect contemporary work relations and which generate unease among managers and workers are the results of the power hegemony, domination and control of modern organizations (Faria, 2004; Freitas, 2000, 2006). These organizations in the particularities of their nature of operation and their dimensions and styles show themselves to be relaxed and dynamic, and they undergo frequent processes of restructuring, which are reduced into managerial fads of all types (Siqueira, 2009a). Their objectives revolve around calling attention to themselves and solidifying themselves based on flexibility in a fluctuating economic market, which is essentially defined by the rigor and pressure of results (Freitas, 2000; Gaulejac, 2007).

Within this context of acceleration through the organizational discourse of promises - which hide and dissimulate the real intentions of the owner of capital regarding the worker- organizations make their ideological beliefs 
appear natural to channel workers' psychic energy and shape their behavior, homogenizing it. They seek to influence human logic and behavior within the context of voluntary servitude in the enthusiastic adherence to management's proposals (Enriquez, 1990; Faria, 2004; Gaulejac, 2007; Pagès et al., 1987; Siqueira, 2009a).

The process of alienation at work is based on the organization's instrumental logic and totalitarian control of behavior and the often-resigned acceptance of the individual (Freddo, 1994; Siqueira \& Mendes, 2009), in which "the individual is socialized culturally within the organization" (Freddo, 1994, p. 28). These facts lead these individuals to lose their critical faculties and place their identities and dreams at risk (Siqueira $\&$ Mendes, 2009). In the absence of meaning, alienated work mortifies these subjects and collectives, turning them into dead work, characterized by experiences of silence and loneliness (Ferreira, 2016).

Loneliness shows itself in its most anguished face, which is difficult to elaborate on the psychic level. Sublimating it makes this difficult, and individuals use broader defense mechanisms to coexist with what is overwhelming them. Loneliness also has another facet, in that these mechanisms are more individual and have little to do with the group level. It is an internal silence that terrorizes in terms of its subjectivity, identification, and idealized objects and desires. It is interesting to say that loneliness is artificially minimized (if that is how we may phrase it) through affection, not from a liberating perspective, but in the control dimension, including the romantic sphere.

Enriquez (1990) emphasizes that it is through love, fascination and seduction that "organizations manage to impose their culture in a subtle manner to dominate the individual's subconsciousness" (Siqueira, 2009a, p. 83). It is more than a loss of autonomy; it is a "pact with the devil: a renouncing of oneself" (Pagès et al., 1987, p.141).

Human beings, within their particularities, control themselves and are destroyed or let themselves be destroyed by an 'evil principle,' of the nonsubject. This principle is in the individual's exterior, power, and imprisonment that is experienced within these organizations as a form of self-destruction (Touraine \& Khosrokhavar, 2004). They are therefore "caught in a spiral from which they cannot escape" (Gaulejac, 2007, p.127). In this manner, individuals distance themselves from the chance to really be themselves. Thus, loneliness means one has little value if there is no individual redirection in terms of the working world, an emancipating repositioning.

Instead of this, individualism is extolled, resulting in a breaking of social ties, the cooling of work relationships, affection and solidarity. With this, 
competitiveness, egotism, and loneliness increase among workers. As Enriquez states (2004/2005, p. 27), "the human who becomes the only one responsible for his or her life, becomes an isolated human." Collective solidarity in this managerial universe has been substituted by the celebration of individual merit (Gaulejac, 2007).

The narcissist within the individual is asked to manifest itself (Freitas, 2000). Organizations that are influenced by managerialism seek to use these narcissistic anxieties (Freitas, 2000), convincing workers of their capacities to feed their ego and promote the realization of a desired perfection which makes it possible to "have projects, forge an identity and construct themselves in terms of their differentiation" (Enriquez, 1990, p. 307). Thus, all of these investments in workers revolve around themselves, making them willing to become "exactly what society values: a winner" (Enriquez, 2004/2005, p. 28).

It may be perceived, therefore, that this manipulation of the worker and the worker's subjectivity in relation to the organization (Faria \& Meneghetti, 2007) traces a utilitarian paradigm in which each worker tries to maximize his or her utility and "becomes objectified, turning into a factor of production" (Siqueira, 2009a, p.40). It is in this sense that organizational management is perverted; humans become mere productive resources (Gaulejac, 2007).

The organization, like the mother who feeds and the father who protects, thus becomes an arena of rivalry for winning the position of the best child, feeding disputes and competition between peers, which are the first signs of withdrawal, suspicion and loneliness. This arena of rivalry can lead the individual to feed more and more loneliness, even within work groups. This is a form of violence against the individual which can lead to suffering and cause illness.

Within the context of suffering, Dujarier (2009, p.122) establishes a wholistic perspective of loneliness in which the individual, the entity that suffers in the work environment, lives daily. This loneliness is expressed by this individual's difficulty in speaking about his or her own suffering. According to the author, this can be dangerous for the employer, given the organizational discourse and the extolling of physical and mental health, a theme confirmed by Siqueira (2009a) in discussing the non-space of those who have been made fragile in some manner. Congruent with this suffering, Johnsen (2016) adds the tedium of work, which is similar to the pathologies of contemporary organizations, such as alienation and depression, which circumscribe monotonous, repetitive work which has lost its meaning. Expressing suffering to clients or users can be taken as an organizational deviation. Speaking with a colleague at work is also risky, especially because 
this person occupies the same working conditions, because those who expose their suffering can be perceived as unqualified or weak.

According to Dujarier (2009), individuals can also speak to those whom they are close to, but who do not have knowledge of the organizational context, the cause of this suffering, but they may not have the patience to listen repeatedly to what the other has to say. There remains for the individual the seeking out of a union lawyer or entering therapy, which may lead to losses in his or her relationship with work.

Loneliness is also present in withdrawal or loss, whether it has to do with work or the meaning of work, due to tedium or a lack of interest and disgust with work (Johnsen, 2016). In these situations, individuals "lose their social existence. They become invisible" (Enriquez, 2004/2005, p. 28). This loneliness can also be experienced due to leaves from work due to physical or psychic illness. Related to this is Gaulejac's observation (2011, p. 38) that cites the expression of Linhart, Rist and Durand (2002), "losing one's job means losing oneself.". And to the extent that the adherence of the individual to the organization increases, there is a greater tendency to be part of the organizational community, as Freitas (2006) terms it, in dealing with categories of the organizational imagination. Exclusion from this community, even if only temporarily, can generate suffering, pain and loneliness. As mentioned by Antunes and Praun (2015), the breaking of the ties of solidarity among workers forms a foundation for an increase in psychic illness in modern organizations.

It is within this context that forms of violence experienced in the work environment have been considered precursors to loneliness and social isolation. An example of this is when the worker no longer identifies with his or her colleague and/or manager, because the relationships of confidence within the contemporary context have given way to numbness, apathy, insensitivity and indifference. As Enriquez states (2006, p. s/n), "men's companion is more and more often loneliness.". More and more "people are more and more isolated, even when their loneliness is "populated"" (Enriquez, 2004/2005, p. 19).

Even in the middle of the multitudes at work, there is loneliness and isolation. This fact can be understood based on the relationship between the individual and the company, which is becoming more and more violent. This violence is present: 1 . In cases of moral harassment perpetrated by narcissistic and destructive leaders; 2 . In the values pushed into the background, when instrumental rationality takes up all available space; 3 . In the objectification and quantification of the individual; 4. In the intensity of work which makes 
it more precarious; 5 . In the silencing of speech and; 6 . In the denial and kidnapping of the individual's subjectivity, which eliminates creativity and provokes the individual's loss of himself or herself (Faria \& Meneghetti, 2007; Ferreira, 2016; Siqueira, 2009b). These are forms of symbolic violence, "smooth, insensitive, and invisible to the victims themselves which are exercised essentially through purely symbolic avenues of communication and knowledge" (Bourdieu, 2007, p.7).

Dejours (1999) emphasizes that within the new ways in which work and management are organized, there is no mention of the violence related to the strict sense of the use of force, given the increasingly frequent use of violence as an instrument of domination which generates suffering, injustice, and mental and somatic pathologies on the part of the worker. In this sense, Dejours (2008, p. 19) states that "the new pathologies related to work today were the first pathologies of loneliness."

\section{BEYOND PLEASURE AND SUFFERING: LONELINESS AS A VIRTUE AND A FULLNESS OF LIFE}

Dujarier (2009, p.120) observes the centrality of work in the social construction and subjectivity of the individual as the: "possibility of redemption (especially among Calvinists) and emancipation (in terms of pre-revolutionary France, for example)." Gaulejac (2011, p.26) presents the contradictory faces of work citing the aspects of "servitude and suffering and liberation and success."

To Lhuilier (2005), work is intimately linked to social relationships with the other; the construction of the subject; the importance of recognition; the construction of identity which occurs based on the other, the demands of the other, and what is useful to the social environment. "Work is a scenario which develops this search for identity which leads subjects to create, manifest and recognize their singularity through their practices" (Lhuilier, 2005, p. 212). Individuality is considered in terms of desire, a mobilization of action, but the focus is always on the other and on the group. In the same time that work is the space for the construction of identities, it is the locus of this exchange.

It is in this sense that Enriquez (2004/2005, p.31) states that "humans only exist through the relationships that they create with others." These statements obviously cannot be denied, but they can be modified especially in relation to the importance of loneliness (including solitary work) in terms 
of the strengthening of individuality. Lhuilier (2005, p. 217), inspired by Arendt, says to the contrary, that action "is never possible in isolation: to be isolated is to be deprived of the capacity to act." We must question, therefore, this great emphasis on the social validation of work and action. It is essential to recall Seneca's analysis (2016) regarding the dangers of depositing a large part of our personal happiness in the hands of others.

In discussing work in the dynamic through which it can be seen as sustenance and the objective of existence, Gaulejac (2011, p.33) states that "work offers a position and status, an identity that makes it possible to define one's place in society compared to other people, (...) indicating belonging and a social identity." And he ends this exposition with a phrase that summarizes this perspective well: "what is essential is not having a job, but existing through it." This is the logic of work that goes beyond sustenance, or in other words, that considers it to be a reason for existence.

It should be noted that in this entire exposition regarding work as a source of pleasure, a stimulus for creativity, the construction of collective works, and being associated with liberty, the reality is not such an idyllic vision and a significant part of paid work is extremely a routine, horizontally and vertically specialized, and is permeated by various forms of symbolic violence which frequently lead to an individual's physical and psychic illness.

The argument proposed at this point in the study does not deny the other or disdain the social, but rather focuses on the need to readjust work in the lives of human beings, and the importance of establishing the proper dimension of work, of solitary spaces, which above all are concerned with affirming life, which is difficult to achieve without a minimal amount of escape from the individual's everyday work dynamics. In light of this argument, it is crucial that we reflect on the role attributed to loneliness.

We look for support, therefore, from philosophy, specifically in the work of Nietzsche, who considers loneliness to be a moral virtue, necessary in the development of a human being's ability to think for him or herself, and to question prevailing values. There is therefore a need to develop a solitary attitude towards life which is not to run from it, which would be strange to the philosopher due to the excellence of affirming life. It is an exit for reflection. "It is in loneliness that authors give themselves over to philosophic reflection; it is the mechanism through which character drinks from the cup of wisdom" (Marton, 2000, p.79).

Nietzsche (2008, p.216) presents loneliness as contemplative, close to the Greek concept of scholé, something that is essential in the search for serenity. According to him, "when you choose to this loneliness, it in no way 
involves renouncing the world; on the contrary, remaining in the practical world would be renouncing, giving into melancholy and self-destruction... this is how one attains serenity." This return to practical life occurs after an intense period of loneliness: "I am thinking again of descending to be together again with my friends and my enemies! Zarathustra can speak again and present and do his best for those whom he loves the most!" (Nietzsche, 2011, p. 80).

Loneliness represents the return to oneself, a moment of reinvigoration, in which upon leaving the field of events, the evaluation of the social field will be different. It is an affirmation of life itself based on a systemic critique of morality. It is leaving the cage created by the designs of the other. Oliveira (2010, p.37) uses a metaphor to represent light to Nietzsche: "the mountain is the place of the solitary philosopher and the market place, the place where we hear the murmur of the moralized herd." He continues noting that "a man with herd morality, domesticated and sick, can no longer externalize his creative forces and becomes hostage to the gregarious precepts of the majority."

In Zarathustra, Nietzsche reflects on the need to flee from the market and its venomous flies, to be far from the seduction of fame, to leave to live a great existence far from the company of the small and the miserable: "flee my friend to your loneliness, to where the air is rude and strong! It's not your fate to swat flies ..." (Nietzsche, 2011, p. 51). And further: "Loneliness! Loneliness, my country! How sweetly and adventurously your voice speaks to me" (Nietzsche, 2011, p.176). "All of my Zarathustra is a dithyramb to loneliness" (Nietzsche, 1995, p.31).

Loneliness anticipates the encounter with the other. It is a form of preparation for being with the other. It is something essential to learning to continue to be oneself. Loneliness is essential to "sharpen one's vision and hone the senses," which causes "its interlocutors to embrace their individual paths on their own" (Marton, 2000, p.84). According to her, it is where one takes advantage of the benefits of silence and pure water. It is in restoring loneliness that we emerge reinvigorated, where there is the possibility of a cure, and it is only from this loneliness, that it is possible for the individual to be aware of his or her singularity. One might say that it makes it possible to be the author of one's own story of life without being influenced by the other. It is to make oneself one's own work of art.

Marton (2000, p. 90) explores an essential element of Nietzsche's interpretation of loneliness in raising the question of cultural Philistines, those who "manipulate those who surround them." We can say that it can be 
a form of emancipation from the discourse and influences of the other and the definition of one's own path. It is leaving the sphere of influence of this other and institutions, blazing the path of the deconstruction of power. According to Nietzsche $(2008$, p.232), ". . . in the middle of the crowd I live like the others and don't think like myself; after a while I begin to get the feeling that they want to banish me from myself, to take my soul away from me."

This vision is similar to another commentator on Nietzsche's work, who emphasizes the absence of God, which requires man to take care of himself, of his joy, affirmation of life and the "moral disengagement in relation to ideas and the ideas professed by others" (Oliveira, 2010, p.25). In this excerpt, the author does not maintain the perspective of loneliness in terms of physical distance, but rather in reevaluating the relationship with the morals of the herd. It would be interesting to analyze this attachment to the ideas of others and the reproduction of organizational discourse, especially in facing the subtle control of individuals in the work environment. We also should remember the figure of Reich's little man (2001) who admired a powerful individual so much that he gave up having his own political positions and placed his destiny in his hands. We risk saying that this is what it means to passively accept the social concepts related to organizational work and culture.

It is questioned, therefore, to what extent work in the third millennium can free up liberating space. Clearly this is part of a collective battle and not something that comes from institutional power. There is a need to reflect on organizational critiques, emphasizing their reproduction in all possible spaces, which will always be marginal, due to the nature of work itself. In the market, ". . everyone talks and no one listens. Someone can announce his truth with bells: merchants will drown out the sound with the clinking of nickels!" (Nietzsche, 2011, p. 176). From an organizational context, market logic in relation to the advance of managerial ideology will squash any murmur of resistance.

Based on Oliveira (2010, p. 32), we can say that "we need to break with the moralizing processes that have been used to train the human animal and annul its individual characteristics which have been termed undignified." And we can continue by noting "that instead of making man love himself, morality has contributed to man's feeling of self-disgust, recognizing in individual characteristics nothing more than inhuman defects and vices."

According to Nietzsche (2011), the search for free will is in making the journey of affirming the plenitude of life and the consciousness of one's own being: "love it with a free spirit and a free heart" (Nietzsche, 2011, p. 17). And we can continue by noting that, "we should make a journey like 
Zarathustra, each one should embrace his or her own destiny. Solitary like Nietzsche, each individual has to become what he or she is. Those who do this, they do not let them speak; those who radiate light, they silence" (Marton, 2000, p. 94).

\section{FINAL CONSIDERATIONS}

Critical studies of the dark side of organizations have concentrated on issues of power, domination, control, exploitation and resistance with an implicit or explicit concern regarding the emancipation of the individual (Linstead, Maréchal, \& Griffin, 2014). Thinking of the different faces of loneliness, this can also be conceived of as a significant resource that can be used to reorient organizational studies, and it can in fact be used in the liberation of the worker.

Contemplating loneliness exclusively as an affect of coexistence and social interaction is limiting it to a social representation of physical exclusion and withdrawal, perceiving it solely as geographic distancing. Looking just from this angle, it tends to restrict loneliness to the field of pathological, degenerate, and lamentable suffering, which is responsible for depressions, suicidal thoughts and emotional numbness. Looking at this phenomenon in the light of an interdisciplinary approach and critical epistemology, we can perceive reflections that enable us to envision other faces of loneliness in the context of contemporary work.

As a symptom of unease at work under the effect of managerial ideology, interpretations allude to the depressing, harmful side of loneliness. This face is omitted by the seduction present in organizational discourses which nurture narcissistic desires in the worker's realization of work. Disillusioned with promises and determined to be the most desirable members of an organization, this tends to cause rivalry, suspicion and the greater fragility in the social ties among employees. Loneliness takes hold of workers, who even though are members of the "team", see themselves as alone and subjectively wounded. The managerial ideology makes the work space an arena of vanities, where being better requires abandonment of the other, requiring a withdrawal from oneself.

Interpretations which portray the virtuous side of loneliness, invest in its creative, restorative, and emancipating potential, making it possible to define it as a threat to managerialism, given its capacity to reveal the understood effects of the practices of submission and exploitation that occur 
in the work place. When loneliness enables individuals to question their values, they are able to broaden their understanding of themselves and the social role of the business world.

Therefore, it cannot be denied that loneliness presents various faces: loneliness in the face of the everyday violence of the work place, the loneliness of work that has lost its meaning, loneliness based on a lack of support, and the loneliness necessary for individuals to perceive their own subjectivity and, needless to say, achieve emancipation and display resistance in the relationship of the individual with the group.

We would like to emphasize the need to broaden the knowledge of the productive and liberating potential that loneliness presents. Reflecting on loneliness and its virtues in terms of the emancipation and growth of the worker implies breaking with the unilateral and singular concept of isolation. It is not restricted to physical distancing, much less to fleeing from life, and can rather be the search to find oneself. It can be a way to reinvigorate and reflect, in order to reposition the values and culture with which employees are indoctrinated, in which behavior is widely formalized, homogeneous and manipulated to the detriment of people being themselves, enabling them to design their own paths in life and live based on an emancipated dimension.

The reflections we have made point to the possibility of various theoretical and empirical studies in the organizational field. In the midst of various new configurations in the working world and transformations in worker identity, thinking of loneliness within the context of differences and diversity in work and organizations, in working conditions and relationships, and in the anonymity of the worker in the face of the organizational dimension could improve the maturity of virtuous interpretations. Bringing loneliness to the table of discussing organizational studies appears to break with the conventional mainstream of human resources management.

Studies of loneliness in telework and work at home which weaken social ties and harm team creativity and spirit, can reveal significant results for the field of organizational studies. In the same way, studies of loneliness in professional absences from work - when workers need to leave work to rediscover themselves - whether they are leaves of absence, vacations, transfers or other types of absence - can illuminate indispensable perspectives in terms of the contemporary working world, both in terms of individual growth or depression due to a lack of work ties. Nonetheless, in addition to studies using the socio-clinical approach and those related to managerial ideology, the results obtained in this essay offer a stimulus for new studies that contemplate loneliness through a virtuous perspective, 
which makes it possible for individuals to find their own identity and be conscious of their own abilities in choosing their own paths with at least a minimum of autonomy and emancipation.

\section{SOLIDÃO E TRABALHO NA CONTEMPORANEIDADE: AS MÚLTIPLAS PERSPECTIVAS DE ANÁLISE}

\section{RESUMO}

Objetivo: Refletir as faces da solidão no contexto do trabalho contemporâneo contemplando-a: 1. como afeto da convivência e da interação social; 2. como sintoma do mal-estar no trabalho, resultado da ideologia gerencialista; e 3. como fonte para o desenvolvimento, revigoramento e a formação do indivíduo.

Originalidade/valor: O estudo torna-se relevante por possibilitar um novo olhar para a solidão no contexto do trabalho como recurso para emancipação do trabalhador.

Design/metodologia/abordagem: O trabalho caracteriza-se como um ensaio teórico, fundamentado em uma revisão de literatura, em periódicos que permeiam diferentes campos de conhecimento (sociologia, psicologia, filosofia e administração), fazendo uma reflexão interdisciplinar entre as correntes que discutem as faces da solidão.

Resultados: Evidenciou-se que a solidão no trabalho contemporâneo pode ser vista como nociva, ante as violências cotidianas no ambiente organizacional, no trabalho que tenha perdido o sentido e na falta de solidariedade entre os trabalhadores ou como virtude necessária para o desenvolvimento e emancipação do fazer sujeito. Embora vista na maioria dos estudos como um fenômeno negativo, ela não se restringe apenas a um distanciamento físico, muito menos à fuga da vida, mas pode também ser a busca do despertar em relação a si mesmo e de reposicionamento dos valores e da cultura adestradora das organizações.

\section{PALAVRAS-CHAVE}

Solidão. Trabalho. Socioclínica. Ideologia Gerencialista. Violência. 


\section{REFERENCES}

Antunes, R., \& Praun, L. (2015). A sociedade dos adoecimentos no trabalho. Serviço Social \& Sociedade, 123, 407-427. Retrieved from http://www.scielo. br/pdf/sssoc/n123/0101-6628-sssoc-123-0407.pdf

Bauman, Z. (2003). Trabajo, consumismo y nuevos pobres. Barcelona, ES: Gedisa.

Bloom, P. (2016). Work as the contemporary limit of life: Capitalism, the death drive, and the lethal fantasy of "work-life balance." Organization, 23(4), 588-606. doi:10.1177/1350508415596604

Bourdieu, P. (2007). A dominação masculina (5th ed.). Rio de Janeiro, RJ: Bertrand Brasil.

Chan, S. H., \& Qiu, H. H. (2011). Loneliness, job satisfaction, and organizational commitment of migrant workers: Empirical evidence from China. International Journal of Human Resource Management, 22 (5), 1109-1127. doi:10.1080/0958 5192.2011.556785

Chertkovskaya, E., Korczynski, M., \& Taylor, S. (2017). The consumption of work: Representations and interpretations of the meaning of work at a UK university. Organization, 00(0), 1-20. Retrieved from https://journals. sagepub.com/doi/full/10.1177/1350508417734056

Dashtipour, P., \& Vidaillet, B. (2017). Work as affective experience: The contribution of Christophe Dejours' "psychodynamics of work." Organization, 24(1), 18-35. doi:10.1177/1350508416668191

Dejours, C. (1999). Violence ou domination? Travailler, 3, 11-29. Retrieved from http://www.comprendre-agir.org/images/fichier-dyn/doc/violence domination_dejours.pdf

Dejours, C. (2006). A banalização da injustiça social (7th ed.). Rio de Janeiro, RJ: Editora FGV.

Dejours, C. (2008). Addendum: Da psicopatologia à psicodinâmica do trabalho. In S. Lancman, \& L. I. Sznelwar (Org.), Christophe Dejours: Da psicopatologia à psicodinâmica do trabalho (pp. 47-104). Rio de Janeiro, RJ: Fiocruz.

Delbridge, R., \& Sallaz, J. J. (2015). Work: Four worlds and ways of seeing. Organization Studies, 36(11), 1449-1462. doi:10.1177/0170840615612021

Dornelas, K. C. A. (2010). Um olhar sobre a solidão feminina e os relacionamentos interpessoais nas histórias de brasileiras e mexicanas (Doctoral dissertation). Universidade Federal do Espírito Santo, Espírito Santo, ES. 
Dujarier, M. (2009). Une analyse sociologique des discours sur la souffrance au travail. In T. Périlleux, \& J. Cultiaux (Org.), Dans destins politiques de la souffrance (pp. 119-132). Toulouse, FR: ERES. doi:10.3917/eres.peril. 2009.01.0119

Enriquez, E. (1990). Da horda ao Estado: Psicanálise do vínculo social. Rio de Janeiro, RJ: Zahar.

Enriquez, E. (2004/2005). Da solidão imposta à uma solidão solidária. Cronos, 5/6(1/2), 19-33. Retrieved from https://periodicos.ufrn.br/cronos/article/ view/3230

Enriquez, E. (2006). O homem do século XXI: Sujeito autônomo ou indivíduo descartável. RAE-eletrônica, 5(1). Retrieved from https://rae.fgv.br/sites/ rae.fgv.br/files/artigos/10.1590_S1676-56482006000100011.pdf

Enriquez, E. (2013). Le travail, essence de l'homme ? Qu'est-ce que le travail? Nouvelle Revue de Psychosociologie, 15(1), 253-272. doi:10.3917/nrp.015. 0253

Faria, J. H. de (2004). Economia política do poder: As práticas do controle nas organizações. Curitiba, PR: Juruá.

Faria, J. H., de \& Meneghetti, F. K. (2007). Sequestro da subjetividade. In J. H. Faria (Org.), Análise crítica das teorias e práticas organizacionais (pp. 45-67). São Paulo, SP: Atlas.

Ferreira, J. B. (2016). Quantos anos de solidão? Violência, assédio moral e paralisia das formas de vida no trabalho. In B. L. Farah (Org.), Assédio moral organizacional: Novas modalidades do sofrimento psíquico nas empresas contemporâneas. São Paulo, SP: LTr.

Freddo, A. C. (1994). O discurso da alienação nas organizações. Revista de Administração Pública, 28(1), 24-33. Retrieved from http://bibliotecadigital. fgv.br/ojs/index.php/rap/article/viewFile/8502/7235

Freitas, M. E. de (2000). Contexto social e imaginário organizacional moderno. Revista de Administração de Empresas, 40(2), 6-15. doi:10.1590/S003475902000000200002

Freitas, M. E. de (2006). Cultura organizacional: Identidade, sedução e carisma (5th ed.). Rio de Janeiro, RJ: Editora FGV.

Freud, S. (1990). Psicologia das massas e análise do ego. In S. Freud, Edição standard brasileira das obras psicológicas completas de Sigmund Freud (pp. 89-179). v. 18. Rio de Janeiro, RJ: Imago.

Fry, J., \& Bloyce, D. (2017). 'Life in the travelling circus': A study of loneliness, work stress, and money issues in touring professional golf. Sociology of Sport Journal, 34(2), 148-159. doi:10.1123/ssj.2017-0002 
Garrett, L. E., Spreitzer, G. M., \& Bacevice, P. A. (2017). Co-constructing a sense of community at work: The emergence of community in coworking spaces. Organization Studies, 38(6), 821-842. doi:10.1177/01708406166 85354

Gaulejac, V. de (2007). Gestão como doença social: Ideologia, poder gerencialista e fragmentação social. São Paulo, SP: Ideias e Letras.

Gaulejac, V. de (2011). Travail: Les raisons de la colère. Paris, FR: Seuil.

Gaulejac, V., \& Takeuti, T. (2013). O âmago da discussão: Da sociologia do indivíduo à sociologia do sujeito. Revista Cronos, 5 (1/2), 59-77. Retrieved from https://periodicos.ufrn.br/cronos/article/view/3233/2623

Gomes, A. M. A. (2001). Solidão: Uma abordagem interdisciplinar pela ótica da Teologia Bíblica Reformada. Fides Reformata, 6(1). Retrieved from http:// cpaj.mackenzie.br/fidesreformata/artigos.php

Graceffa, S., \& de Heusch, S. (2017). Reinventing the world of work. Transfer: European Review of Labour and Research, 23(3), 359-365. doi:10.1177/1024 258917707870

Granter, E. (2009). Critical social theory and the end of work. Farnham, UK: Ashgate.

Hanique, F. (2009). Enjeux théoriques et méthodologiques de la sociologie clinique. Informations Sociales, 156(6), 32-40. Retrieved from https://www. cairn.info/revue-informations-sociales-2009-6-page-32.htm

Johnsen, R. (2016). Boredom and organization studies. Organization Studies, 37(10), 1403-1415. doi:10.1177/0170840616640849

Kuznier, T. P. (2016). Tradução, adaptação e validação da UCLA Loneliness Scale (version 3) para o português do Brasil em uma amostra de idosos (Doctoral dissertation). Universidade Federal de Minas Gerais, Belo Horizonte, MG.

Lhuilier, D. (2005). Trabalho. In J. Barus-Michel, E. Enriquez, \& A. Lévy, Dicionário de psicossociologia (pp. 210-219). Lisboa, PT: Climepsi.

Linhart, D., Rist, B., \& Durand, E. (2002). Perte d'emploi, perte de soi. Toulouse, FR: Éditions Érès.

Linstead, S., Maréchal, G., \& Griffin, R. W. (2014). Theorizing and researching the dark side of organization. Organization Studies, 35(2), 165-188. Retrieved from http://journals.sagepub.com/doi/10.1177/0170840613515402. doi:10. $1177 / 0170840613515402$

Marton, S. (2000). Silêncio, solidão. Cadernos Nietzsche, 9(2), 79-105. Retrieved from http://www.gen.fflch.usp.br/sites/gen.fflch.usp.br/files/upload/ cn_09_04\%20Marton.pdf 
Nietzsche, F. (1995). Ecce Homo. São Paulo, SP: Companhia das Letras.

Nietzsche, F. (2008). Aurora: Reflexões sobre os pensamentos morais. São Paulo, SP: Companhia das Letras.

Nietzche, F. (2011). Assim falou Zaratustra. São Paulo, SP: Companhia das Letras.

Nunes, C. G. F. \& Silva, P. H. I. (2018). A sociologia clínica no Brasil. Revista Brasileira de Sociologia, 6(12), 181-199. Retrieved from http://www. sbsociologia.com.br/revista/index.php/RBS/article/view/239/178. doi:10. 20336/rbs.239

Öge, E., Çetin, M., \& Top, S. (2018). The effects of paternalistic leadership on workplace loneliness, work family conflict and work engagement among air traffic controllers in Turkey. Journal of Air Transport Management, 66(2018), 25-35. doi:10.1016/j.jairtraman.2017.10.003

Oliveira, J. (2010). A solidão como virtude moral em Nietzsche. Curitiba, PR: Champagnat.

Ozcelik, H., \& Barsade, S. G. (2018). No employee an island: Workplace lonelıness and job performance. Academy of Management Journal, 61(6). Retrieved from https://journals.aom.org/doi/10.5465/amj.2015.1066. doi:10.5465/amj. 2015.1066

Pagès, M., Bonetti, M., Gaulejac, V., \& Descendre D. (1993). O poder das organizações: A dominação das multinacionais sobre os indivíduos. São Paulo, SP: Atlas.

Pocinho, M., \& Macedo, E. (2017). Solidão: Um construto complexo. Interações: sociedade e as Novas Modernidades, (32), 53-66. Retrieved from http://www. interacoes-ismt.com/index.php/revista/article/view/399

Praun, L. (2016). A solidão dos trabalhadores: sociabilidade contemporânea e degradação do trabalho. Cadernos de Psicologia Social do Trabalho, 19(2), 147-160. doi:10.11606/issn.1981-0490.v19i2p147-160

Reich, W. (2001). Escute, Zé-Ninguém! São Paulo, SP: Martins Fontes.

Santas, G., Isik, O., \& Demir, A. (2016). The effect of loneliness at work; work stress on work alienation and work alienation on employees' performance in Turkish health care institution. South Asian Journal of Management Sciences, 10(2), 30-38. doi:10.21621/sajms.2016102.03

Sêneca, L. A. (2016). Edificar-se para a morte. Petrópolis, RJ: Vozes.

Sewell, G., \& Taskin, L. (2015). Out of sight, out of mind in a new world of work? Autonomy, control, and spatiotemporal scaling in telework. Organization Studies, 36(11), 1507-1529. doi:10.1177/017084 0615593587 
Siqueira, M. V. S. (2009a). Gestão de pessoas e discurso organizacional (2nd ed.). Curitiba, PR: Juruá.

Siqueira, M. V. S. (2009b). Violência no trabalho e o homem descartável: Um estudo de aproximação entre a sociologia clínica e a psicodinâmica do trabalho. Anais do II Encontro de Gestão de Pessoas e Relações de Trabalho ENGPR, Curitiba, PR, Brasil.

Siqueira, M. V. S., \& Mendes, A. M. (2009). Gestão de pessoas no setor público e a reprodução do discurso no setor privado. Revista do Serviço Público, 60(3), 241-250. Retrieved from https://revista.enap.gov.br/index. php/RSP/article/view/25/22

Symon, G., \& Pritchard, K. (2015). Performing the responsive and committed employee through the sociomaterial mangle of connection. Organization Studies, 36(2), 241-263. doi:10.1177/0170840614556914

Tomei, P. A., \& Fortunato, G. (2008). A solidão no poder nas organizações. Organizações \& Sociedade, 15(47), 13-31. doi:10.1590/S1984-92302008000 400001

Touraine, A., \& Khosrokhavar, F. (2004). A busca de si: Diálogos sobre o sujeito. Rio de Janeiro, RJ: Difel.

Valencia, A. S. (2016). Immaterial labor and the determination of social class. Critical Sociology, 42(3), 357-369. doi:10.1177/0896920514536591

\section{AUTHOR NOTES}

Marcus V. S. Siqueira, Escola de Administração de Empresas de São Paulo (Eaesp), Fundação Getúlio Vargas (FGV); Cledinaldo A. Dias, Department of Management and Economics, Universidade Federal de Lavras (UFLA); \& Bárbara N. Medeiros, Faculdade de Administração, Contabilidade, Economia e Gestão de Políticas Públicas (FACE), Universidade de Brasília (UnB).

Marcus V. S. Siqueira is now Associate Professor at Faculdade de Administração, Contabilidade, Economia e Gestão de Políticas Públicas (FACE) at Universidade de Brasília (UnB); Cledinaldo A. Dias is now PhD student in Administration at Faculdade de Administração, Contabilidade, Economia e Gestão de Políticas Públicas (FACE) at Universidade de Brasília (UnB), Adjunct Professor at Universidade Estadual de Montes Claros (Unimontes) and at Universidade Federal de Minas Gerais (UFMG) and scholarship student of Fundação de Amparo à Pesquisa do Estado de Minas Gerais (Fapemig); Bárbara N. Medeiros is now PhD scholarship student in Administration of Coordenação de Aperfeiçoamento de Pessoal de Nível Superior (Capes) at Faculdade de Administração, Contabilidade, Economia e Gestão de Políticas Públicas (FACE) at Universidade de Brasília (UnB).

Correspondence concerning this article should be addressed to Marcus V. S. Siqueira, Campus Universitário Darcy Ribeiro, Prédio da FACE, Asa Norte, Brasília, Distrito Federal, Brazil, CEP 70910-900.

E-mail: marc-vs@uol.com.br 


\section{EDITORIAL BOARD}

Editors-in-chief

Janette Brunstein

Silvio Popadiuk

Associated Editor

Silvia Marcia Russi de Domênico

Technical Support

Vitória Batista Santos Silva

\section{EDITORIAL PRODUCTION}

Publishing Coordination Irina Migliari

Layout Designer

Emap

\section{Copyeditor}

Irina Migliari (English)

Graphic Designer

Carlos Villarruel (Portuguese)

\section{Language Editor}

Daniel de Almeida Leão (English)

Irina Migliari (Portuguese) 